\title{
Genotype based Risk Predictors for Polycystic Ovary Syndrome in Western Saudi Arabia
}

\author{
Sherin Bakhashab ${ }^{1,2, *}$ \& Nada Ahmed 1 \\ ${ }^{1}$ Biochemistry Department, King Abdulaziz University, Jeddah, P.O. Box 80218, Saudi Arabia; ${ }^{2}$ Centre of Innovation in Personalized \\ Medicine, King Abdulaziz University, Jeddah, P.O. Box 80216, Saudi Arabia; Sherin Bakhashab - Phone: +966 126400000 ; E-mail: \\ sbakhashab@kau.edu.sa; Nada Ahmad: E-mail: nahmed0028@stu.kau.edu.sa; *Corresponding author
}

Received November 14, 2019; Revised November 28, 2019; Accepted December 7, 2019; Published December 10, 2019

\begin{abstract}
:
Polycystic ovary syndrome (PCOS) is the most common endocrine disease among premenopausal women. The genetic risk of PCOS in the Saudi population is still unclear. Therefore, it is of interest to study the genotype and allele frequency for six gene variants (THADA rs13429458, TOX3 rs4784165, FSHRrs2268361, YAP1 rs1894116, RAB5B rs705702, and HMGA2 rs2272046) in patients with PCOS in western Saudi population. The study included 95 PCOS patients and 94 normal ovulatory females as controls. Genotyping was performed using $\mathrm{TaqMan}^{\mathrm{TM}}$ real-time polymerase chain reaction assays. There was significant link between the THADA rs13429458 variant and PCOS. Homozygosity in allele A of the rs13429458 variant was correlated with hyperandrogenism (HA) risk. Homozygosity in the T allele of the FSHR rs2268361 variant was associated with normal levels of AMH among non-PCOS women. The THADA rs13429458 and TOX3 rs4784165 variants were significantly associated with the combined oligo/amenorrhea (OA) and polycystic ovarian morphology subgroups while the HMGA2 rs2272046 variant was significantly associated with the combined HA and OA subgroup. Thus, results show the genetic risk of the THADA rs13429458, TOX3 rs4784165, and HMGA2 rs2272046 variants on PCOS patients in the western Saudi population.
\end{abstract}

Keywords: Polycystic ovary syndrome; THADA; TOX3; FSHR; YAP1; RAB5B; HMGA2

\section{Background:}

The diagnostic criteria for polycystic ovary syndrome (PCOS), a complex endocrine disorder affecting reproductive-aged women, have evolved since the disorder was first recognized. The National Institutes of Health first defined PCOS as the presence of clinical or biochemical hyperandrogenism (HA) comorbid with oligo/amenorrhea (OA) [1]. The Rotterdam consensus added the polycystic ovarian morphology (PCOM) phenotype, and the diagnosis was redefined as the presence of two out of the three conditions[2]. The Androgen Excess Society subsequently considered HA a key component in PCOS diagnosis [3]. The Rotterdam criteria was endorsed by an Endocrine Society clinical practice guideline [4]. According to the diagnostic criteria, the prevalence of PCOS varies worldwide but is generally 6-20\% [5-7]. Although there are no prevalence studies that include the entire kingdom of Saudi Arabia, a study conducted in the city of Madinah found a prevalence of $32.5 \%$ [8]. Associated with significant multiple clinical manifestations including reproductive, metabolic, and psychological disorders [9-15], PCOS represents $80 \%$ of anovulatory infertility cases [10], and $80-85 \%$ of women with clinical HA have PCOS [16, 17]. Manifestation of the disorder varies depending upon the particular diagnostic criteria. Patients diagnosed according to the Rotterdam and $\mathrm{NIH}$ criteria are at higher risk of developing reproductive and metabolic disorders such as infertility and type-2 diabetes [18-21]. The etiology of PCOS is not entirely clear; however, the disease is primarily attributed to multiple genetic and environmental factors aggravated by obesity [22]. 

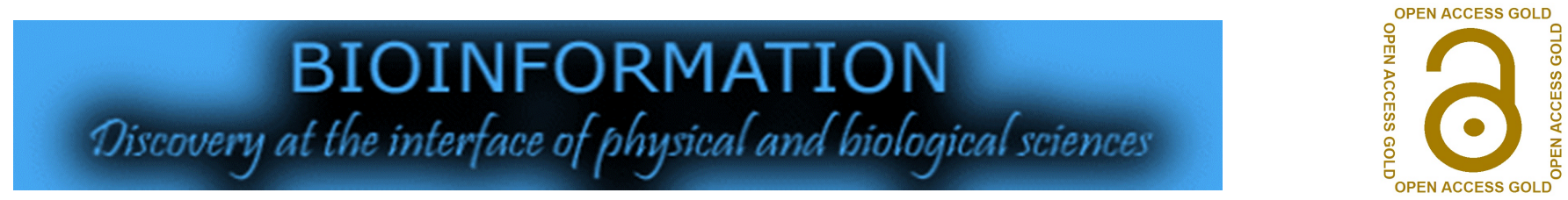

Heritability of PCOS has been confirmed through twin, family, candidate gene, and genome-wide association studies (GWAS) [2327]. Two GWAS conducted within the Han Chinese population identified 15 risk single nucleotide polymorphisms (SNPs) at 11 loci $[23,26]$. Another large-scale GWAS of European Caucasian woman identified six relevant genetic loci [28]. Recently, four studies of European populations confirmed the association of many loci with PCOS [29-32]. The common SNPs correlating to PCOS in women of Chinese and European ancestry were rs13429458 associated with thyroid adenoma (THADA), rs4784165 in the TOX high mobility group box family member 3(TOX3), rs2268361 in the folliclestimulating hormone receptor (FSHR), rs1894116 in yes-associated protein 1 (YAP1), rs705702 in ras-related protein 5B (RAB5B), and rs2272046 in high mobility group AT-hook 2 (HMGA2) [23, 26, 2832].

The THADA gene encodes the thyroid adenoma-associated protein, expressed in the pancreas, adrenal medulla, thyroid, adrenal cortex, testis, thymus, small intestine, and stomach[33]. It was first identified as a target of 2 p21 chromosomal aberrations in benign thyroid adenomas, where it disrupted and fused to an intron of peroxisome proliferator-activated receptor gamma (PPAR $\gamma)$ [33]. The protein encoded by TOX3 gene may alter chromatin structure by bending and unwinding DNA [34]. In addition, TOX3 can interact with the $\mathrm{Cbp} / \mathrm{P} 300$ interacting transactivator containing the Glu/Asp rich carboxy-terminal domain 1 (CITED1) and increase its transcription [35]. As a transcription co-regulator, CITED enhances the activity of transcription factors such estrogen receptors[36].The FSHR variant rs2268361 was determined to be related to the ovarian response to $\mathrm{FSH}$ [37].Inactivating mutations of FSHR lead to hypergonadotropic hypogonadism and preantral stage follicle stagnation [37]. HMGA2 is involved in a IGF2 mRNA binding protein 2 (IMP2) pathway, shown to be activated in PCOS patients and capable of promoting the proliferation of granulosa cells [38]. Moreover, HMGA2 is important in modulating glucose transporter type 4 expressions [39]. The YAP1 gene is one of the transcriptional targets of the Hippo pathway, which controls organ size by regulating cell growth, proliferation, and apoptosis [40] while the $R A B 5 B$ gene is involved in protein trafficking, endocytotic processes and receptor recycling [41-43]. Although many studies have demonstrated the association of specific loci with PCOS in populations of Chinese and European Caucasian ancestry, it is not known whether these loci could contribute to PCOS susceptibility in Saudi women. The aim of this study was to determine in the western Saudi population the presence of common PCOS variants detected previously in Chinese and European Caucasian women. In this population, we also investigated the association between the variants and PCOS clinical symptoms and subgroups.

\section{Materials and Methods: \\ Study Design:}

The power calculation, inclusion and exclusion criteria for this casecontrol study have been previously explained [44]. In summary, 95 PCOS patients diagnosed according to the Rotterdam criteria were compared with 94 women with normal ovulation. The clinical and biochemical measures for the diagnosis were described [44]. Patients and controls were recruited either from the Obstetrics and Gynecology Clinics, King Abdulaziz University Hospital or the Centre of Innovation in Personalized Medicine (CIPM), KAU, Jeddah, Saudi Arabia between 2016-2018. The study was approved by the Biomedical Ethics Unit, Faculty of Medicine, KAU (approval number: 407-15), and written informed consent was obtained from participants prior to sample collection. The study was conducted in accordance with the Declaration of Helsinki. The PCOS patients were divided into four subgroups according to their clinical symptoms. Each subgroup was tested individually to investigate whether the associations between SNPs and PCOS were absolute or relative to combined symptoms. After classification of the patients into subgroups, the sample size was 82 as 13 patients were excluded to avoid misleading results as the third symptom (HA) was not investigated (Table 1).

\begin{tabular}{ll}
\multicolumn{2}{l}{ Table 1: Classification of PCOS into groups according to clinical symptoms } \\
\cline { 1 - 2 } PCOS Subgroup & Frequency \\
\cline { 1 - 2 } Full PCOS (HA + OA + PCOM) & 42 \\
Non-PCOM (HA + OA) & 6 \\
Non-hyperandrogenic (OA + PCOM) & 25 \\
Ovulatory (HA +PCOM) & 9 \\
Total samples & 82 \\
HA: hyperandrogenism. OA: oligo/amenorrhea. PCOM: polycystic ovarian \\
morphology.
\end{tabular}

Table 2: Clinical characteristics of PCOS patients and control subjects

\begin{tabular}{llll}
\hline Variable & Control $(\mathrm{n}=94)$ & PCOS patients $(\mathrm{n}=95)$ & $\mathrm{p}$-value \\
\hline Age $($ years $)$ & $21.0 \pm 3$ & $22.0 \pm 9.0$ & $0.015^{*}$ \\
BMI $\left(\mathrm{kg} / \mathrm{m}^{2}\right)$ & $22.7 \pm 5.9$ & $24.56 \pm 7.34$ & $0.003^{* *}$ \\
$\mathrm{LH}(\mathrm{IU} / \mathrm{ml})$ & $5.7 \pm 5.7$ & $9.0 \pm 8.7$ & $0.001^{* *}$ \\
FSH $(\mathrm{IU} / \mathrm{ml})$ & $4.6 \pm 2.6$ & $4.8 \pm 2.4$ & 0.339 \\
$\mathrm{LH} / \mathrm{FSH} \mathrm{ratio}$ & $1.2 \pm 1.5$ & $1.9 \pm 1.6$ & $0.001^{* *}$ \\
AMH $(\mathrm{ng} / \mathrm{ml})$ & $2.3 \pm 1.4$ & $4.8 \pm 4.76$ & $<0.0001^{* * *}$ \\
\hline
\end{tabular}

The values are expressed as median $\pm \mathrm{IQR}, p$-values were calculated using the MannWhitney test for non-normal distribution data. $p$-value $<0.05$ is statistically significant. BMI: body mass index; LH: luteinizing hormone; FSH: follicle stimulating hormone; AMH: anti-Müllerian hormone. ${ }^{*} p<0.05,{ }^{* *} p<0.01,{ }^{* * *} p<0.001$ 


\section{BIOINFORMATION \\ Discovery at the interface of physical and biological sciences}

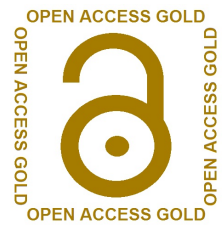

Table 3: Genotype and allele distributions of the six SNPs

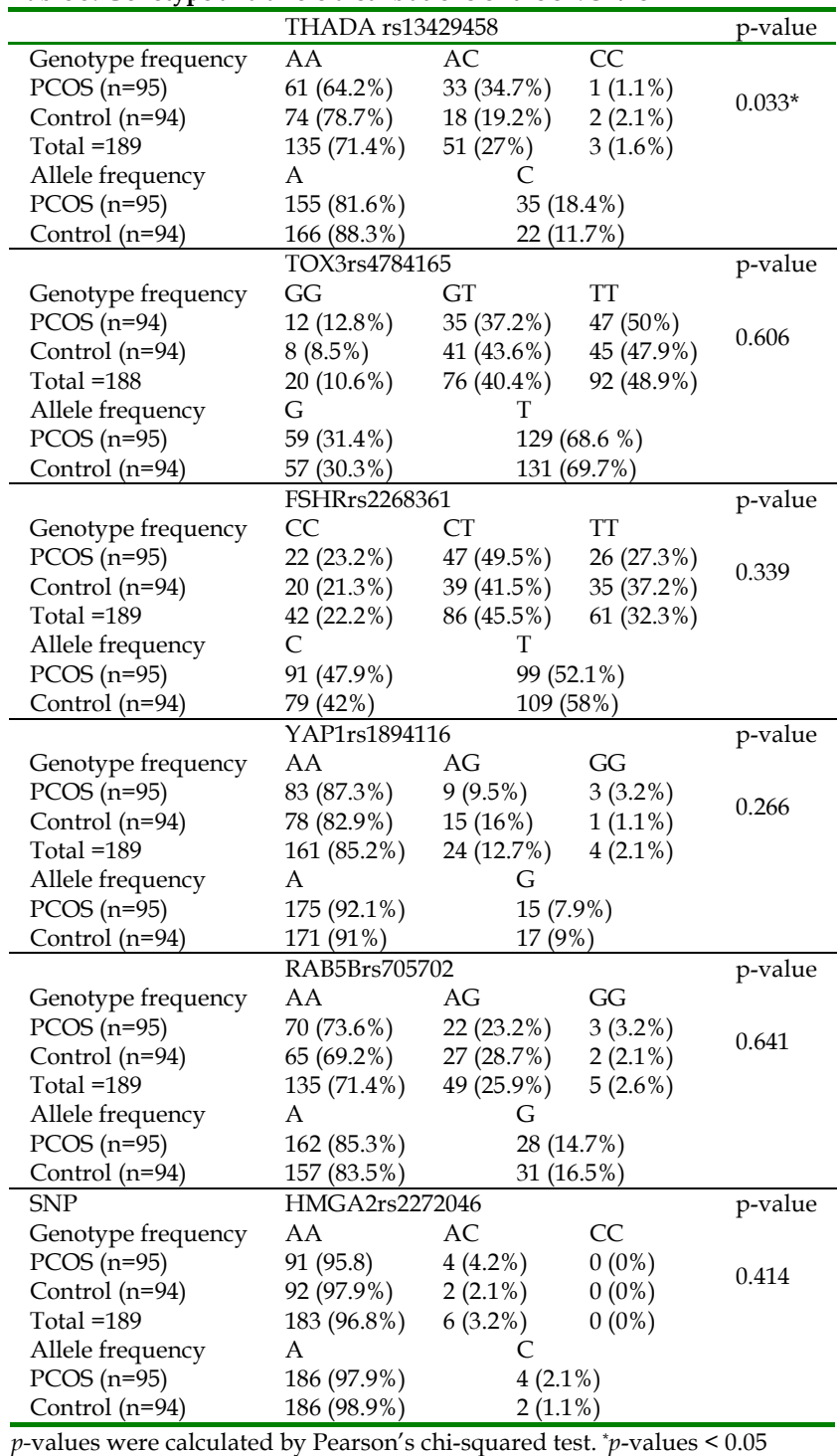

\section{Genotyping:}

The QIAamp DNA Mini Blood Kit (Qiagen, Hilden, Germany) was used to isolate genomic DNA from peripheral whole blood according to the manufacturer's instructions. TaqMan ${ }^{\mathrm{TM}}$ SNP Genotyping Assays (Thermo Fisher Scientific, Waltham, MA, USA) were used for the genotyping of THADA variant rs13429458 (assay ID: C_30817938_10), TOX3 variant rs4784165 (assay ID: C_30765160_10), FSHR variant rs2268361 (assay ID:
C 11813031_1_), YAP1 variant rs1894116 (assay ID:C_11480397_10) , RAB5B variant rs705702 (assay ID:C_3188034_10), and HMGA2 variant rs2272046 (assay ID: C_15961809_10). Allelic PCR products were analyzed using the Quant Studio 12K Flex Real-Time PCR System (Thermo Fisher Scientific).

Table 4: Relationship between the six variants and HA phenotype in the PCOS group

\begin{tabular}{|c|c|c|c|c|}
\hline SNPs & Gene & Genotype & $\begin{array}{l}\text { Frequency } \\
\text { With HA/ without HA }\end{array}$ & $\mathrm{p}$-value \\
\hline \multirow[t]{3}{*}{ rs13429458 } & THADA & AA & $43 / 15$ & $0.031^{*}$ \\
\hline & & AC & $15 / 15$ & \\
\hline & & $\mathrm{CC}$ & $0 / 1$ & \\
\hline \multirow[t]{3}{*}{ rs4784165 } & TOX3 & GG & $6 / 6$ & 0.344 \\
\hline & & GT & $24 / 9$ & \\
\hline & & $\mathrm{TT}$ & $27 / 16$ & \\
\hline \multirow[t]{3}{*}{ rs2268361 } & FSHR & $\mathrm{CC}$ & $12 / 9$ & 0.401 \\
\hline & & $\mathrm{CT}$ & $33 / 13$ & \\
\hline & & TT & $13 / 9$ & \\
\hline \multirow[t]{3}{*}{ rs1894116 } & YAP1 & AA & $51 / 26$ & 0.816 \\
\hline & & $\mathrm{AG}$ & $5 / 4$ & \\
\hline & & GG & $2 / 1$ & \\
\hline \multirow[t]{3}{*}{ rs705702 } & $R A B 5 B$ & AA & $42 / 24$ & 0.871 \\
\hline & & AG & $14 / 6$ & \\
\hline & & GG & $2 / 1$ & \\
\hline \multirow[t]{3}{*}{ rs2272046 } & HMGA2 & AA & $55 / 30$ & 0.673 \\
\hline & & AC & $3 / 1$ & \\
\hline & & $\mathrm{CC}$ & $0 / 0$ & \\
\hline
\end{tabular}

The $p$-values were calculated by chi-squared test. HA: hyper androgenism. ${ }^{*} p$-values < 0.05

\section{Statistical analysis:}

Data analysis was conducted using the IBM SPSS software version 24 (SPSSTM Inc., NY, USA). The participants clinical characteristics were expressed as median \pm inter quartile range (IQR), and $p$-values were calculated using the Mann-Whitney test as the data were nonnormally distributed. The genotype and allele data were expressed as frequencies. The differences between study groups were analyzed using the chi-squared test. Multinomial logistic regression was used to examine the association of the variants with PCOS clinical variables. Values of $p<0.05$ were considered statistically significant.

Results:

All participant clinical parameters are listed in Table 2 . 


\section{BIOINFORMATION}

\section{Discovery at the interface of physical and biological sciences}

Table 5: Relationship between the six variants and AMH cutoff level in PCOS and control groups

\begin{tabular}{|c|c|c|c|c|c|}
\hline SNPs & Gene & Tested group & Genotype & $\begin{array}{l}\text { Frequency } \\
\text { AMH }>3.19 / \\
\text { AMH }<3.19\end{array}$ & p-value \\
\hline \multirow[t]{2}{*}{ rs13429458 } & THADA & $\begin{array}{l}\text { PCOS } \\
(n=79)\end{array}$ & $\begin{array}{l}\text { AA } \\
\text { AC } \\
\text { CC }\end{array}$ & $\begin{array}{l}34 / 14 \\
22 / 8 \\
1 / 0\end{array}$ & 0.799 \\
\hline & & $\begin{array}{l}\text { Control } \\
(n=69)\end{array}$ & $\begin{array}{l}\text { AA } \\
\text { AC } \\
\text { CC }\end{array}$ & $\begin{array}{l}18 / 36 \\
3 / 12 \\
0 / 0\end{array}$ & 0.321 \\
\hline \multirow[t]{2}{*}{ rs4784165 } & TOX3 & $\begin{array}{l}\text { PCOS } \\
(n=78)\end{array}$ & $\begin{array}{l}\text { GG } \\
\text { GT } \\
\text { TT }\end{array}$ & $\begin{array}{l}6 / 4 \\
20 / 9 \\
30 / 9\end{array}$ & 0.520 \\
\hline & & $\begin{array}{l}\text { Control } \\
(n=69)\end{array}$ & $\begin{array}{l}\text { GG } \\
\text { GT } \\
\text { TT }\end{array}$ & $\begin{array}{l}1 / 4 \\
11 / 18 \\
9 / 26\end{array}$ & 0.498 \\
\hline \multirow[t]{2}{*}{ rs2268361 } & FSHR & $\begin{array}{l}\text { PCOS } \\
(n=79)\end{array}$ & $\begin{array}{l}\text { CC } \\
\text { CT } \\
\text { TT }\end{array}$ & $\begin{array}{l}13 / 5 \\
27 / 14 \\
17 / 3\end{array}$ & 0.293 \\
\hline & & $\begin{array}{l}\text { Control } \\
(n=69)\end{array}$ & $\begin{array}{l}\text { CC } \\
\text { CT } \\
\text { TT }\end{array}$ & $\begin{array}{l}4 / 11 \\
13 / 13 \\
4 / 24\end{array}$ & $0.016^{*}$ \\
\hline \multirow[t]{2}{*}{ rs1894116 } & YAP1 & $\begin{array}{l}\text { PCOS } \\
(n=79)\end{array}$ & $\begin{array}{l}\text { AA } \\
\text { AG } \\
\text { GG }\end{array}$ & $\begin{array}{l}49 / 19 \\
5 / 3 \\
3 / 0\end{array}$ & 0.466 \\
\hline & & $\begin{array}{l}\text { Control } \\
(n=69)\end{array}$ & $\begin{array}{l}\text { AA } \\
\text { AG } \\
\text { GG }\end{array}$ & $\begin{array}{l}17 / 42 \\
4 / 5 \\
0 / 1\end{array}$ & 0.510 \\
\hline \multirow[t]{2}{*}{ rs705702 } & $R A B 5 B$ & $\begin{array}{l}\text { PCOS } \\
(n=79)\end{array}$ & $\begin{array}{l}\text { AA } \\
\text { AG } \\
\text { GG }\end{array}$ & $\begin{array}{l}43 / 16 \\
13 / 4 \\
1 / 2\end{array}$ & 0.298 \\
\hline & & $\begin{array}{l}\text { Control } \\
(n=69)\end{array}$ & $\begin{array}{l}\text { AA } \\
\text { AG } \\
\text { GG }\end{array}$ & $\begin{array}{l}15 / 32 \\
5 / 15 \\
1 / 1\end{array}$ & 0.708 \\
\hline \multirow[t]{2}{*}{ rs2272046 } & HMGA2 & $\begin{array}{l}\text { PCOS } \\
(n=79)\end{array}$ & $\begin{array}{l}\text { AA } \\
\text { AC } \\
\text { CC }\end{array}$ & $\begin{array}{l}54 / 22 \\
3 / 0 \\
0 / 0\end{array}$ & 0.273 \\
\hline & & $\begin{array}{l}\text { Control } \\
(n=69)\end{array}$ & $\begin{array}{l}\text { AA } \\
\text { AC } \\
\text { CC }\end{array}$ & $\begin{array}{l}21 / 47 \\
0 / 1 \\
0 / 0\end{array}$ & 0.505 \\
\hline
\end{tabular}

The $p$-values were calculated by chi-squared test. ${ }^{*} p$-values $<0.05$

There was a significant link between $\mathrm{AMH}$ at the previously determined [45] cutoff level $(3.19 \mathrm{ng} / \mathrm{ml})$ and FSHR variant rs2268361 in the control group ( $p=0.016$, Table 5). Multinomial logistic regression showed a significant association between the TT genotype of the rs2268361 variant and normal levels of $\mathrm{AMH}$ $(<3.19)(\mathrm{OR}=6.2, \mathrm{~B}=1.821, p=0.009)$. Hence, homozygosity in the $\mathrm{T}$ allele of rs2268361 is potentially protective, associated with normal levels of AMH among non-PCOS women. No relationship was detected between the other clinical parameters including obesity, OA, and PCOM, and the six SNPs using the chi-squared test.

ISSN 0973-2063 (online) 0973-8894 (print)
Allele and genotype frequency:

The genotype distribution and allele frequencies of the six SNPs are listed in Table 3. There was significant relationship between PCOS and THADA rs13429458 $(p=0.033)$, but no link was detected with the other genetic variants.

The association of the six variants with PCOS clinical characteristics

There was a significant relationship between THADA variant rs13429458 and HA phenotype in the PCOS group $(p=0.031$, Table $4)$ by the chi-squared test. Multinomial logistic regression revealed that the AA genotype in THADA variant rs13429458 was positively correlated with higher frequency of $\mathrm{HA}$ than the AC genotype (OR $=2.9, \mathrm{~B}=1.053, p=0.026$ ). Therefore, homozygosity in allele $\mathrm{A}$ in rs13429458 variant is predicted as a risk genotype associated with HA.

Table 6: The correlation of THADA rs13429458, TOX3 rs4784165, and HMGA2 rs2272046 with PCOS subgroups

\begin{tabular}{|c|c|c|c|c|c|}
\hline SNPs & Gene & Subgroup & Genotype & $\begin{array}{l}\text { PCOS subgroup } \\
\text { frequency }\end{array}$ & $\mathrm{p}$-value \\
\hline rs13429458 & THADA & $\begin{array}{l}\mathrm{OA}+\mathrm{PCOM} \\
(\mathrm{n}=25)\end{array}$ & $\begin{array}{l}\mathrm{A} / \mathrm{A} \\
\mathrm{A} / \mathrm{C} \\
\mathrm{C} / \mathrm{C}\end{array}$ & $\begin{array}{l}12(48 \%) \\
12(48 \%) \\
1(2 \%)\end{array}$ & $0.009^{* *}$ \\
\hline rs4784165 & TOX3 & $\begin{array}{l}\mathrm{OA}+\mathrm{PCOM} \\
(\mathrm{n}=25)\end{array}$ & $\begin{array}{l}\text { G/G } \\
G / T \\
T / T\end{array}$ & $\begin{array}{l}6(24 \%) \\
5(20 \%) \\
14(56 \%)\end{array}$ & $0.028^{*}$ \\
\hline rs2272046 & HMGA2 & $\begin{array}{l}\mathrm{HA}+\mathrm{OA} \\
(\mathrm{n}=6)\end{array}$ & $\begin{array}{l}\mathrm{A} / \mathrm{A} \\
\mathrm{A} / \mathrm{C} \\
\mathrm{C} / \mathrm{C}\end{array}$ & $\begin{array}{l}5(83.3 \%) \\
1(16.7 \%) \\
0(0 \%)\end{array}$ & $0.043^{*}$ \\
\hline
\end{tabular}

THADArs13429458 and TOX3rs4784165 variants are correlated to the OA+PCOM subgroup

The PCOS group was divided into four subgroups according to the clinical symptoms. There was significant correlation between the THADA rs13429458 and TOX3 rs4784165 SNPs and the OA+PCOM subgroup $(p=0.009, p=0.028$ respectively, Table 6 ).

\section{HMGA2rs2272046 variant is correlated to HA+OA subgroup}

The HMGA2variant rs2272046 showed a significant correlation with the HA+OA subgroup ( $p=0.043$, Table 6$)$. No other correlations were detected among other variants within PCOS subgroups.

\section{Discussion}

In the last two decades, numerous studies have focused on the genetic pathogenesis of PCOS in order to understand the genetic predisposition to the disorder. In the present study, we examined six previously reported PCOS-associated SNPs identified collectively through GWAS in populations of Chinese Han and 

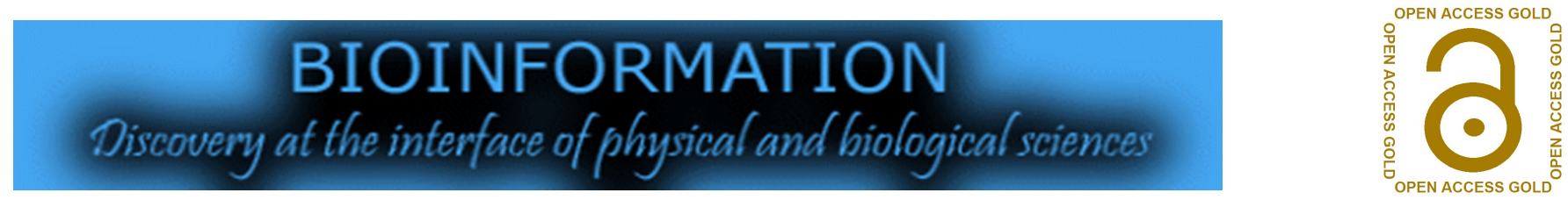

European ancestry [23, 26, 28-32] to investigate their association in the Saudi population.

Of the six SNPs, only the THADA rs13429458 variant was associated with PCOS. This was also found in previous studies of populations with Chinese and European ancestry [23, 26, 28]. The same association was found in a study of the Hainan Chinese population [46]. Furthermore, a family-based analysis of PCOS susceptibility loci on chromosome 2 p21 in the Han Chinese population showed a significant association of rs13429458 with risk of PCOS [47]. Two studies of Caucasian patients concluded that the genotype distribution of rs13429458 did not differ significantly between the patient and control groups [48, 49]. In contrast, two studies of European populations showed no association between rs13429458 and PCOS [30, 32].

The thyroid adenoma-associated protein encoded by the THADA gene is expressed in many organs [33].One GWAS reported the association of THADA with type 2 diabetes particularly through a probability effect on pancreatic beta-cell function [50]. As a result, such a protein would be expected to affect various body processes, not unlike PCOS, which is characterized by dysfunction in multiple organ systems. In the present study, it was correlated in PCOS women with the HA phenotype. This may provide clues to the role of rs13429458 in the etiology of PCOS, as HA is one of the clinical symptoms of PCOS. Previously, the AA genotype for rs13429458 in THADA was detected in different phenotypes to be associated with increased LH, testosterone levels, and the LH/FSH ratio in subjects with PCOS [51]. Moreover, the genotype frequency distribution of rs13429458 was not influenced by hirsutism or increased metabolic parameters, including fasting glucose and insulin level [48].

It was demonstrated that the $\mathrm{AMH}$ receptors expressed in the brain may be involved in initiation of gonadotropin-releasing hormone $(\mathrm{GnRH})$ release from hypothalamic neurons [52]. GnRH causes the pituitary gland in the brain to make and secrete FSH [53] which may explain our finding correlation of the FSHR rs2268361 variant and $\mathrm{AMH}$ at cutoff level in the control group. Furthermore, FSH, as well as $\mathrm{AMH}$, contributes to follicle development, and $\mathrm{AMH}$ preserves the follicles in the primordial stage, estimates the number of ovum in the ovaries, thereby indicating the ovary reserve [54, 55]. In PCOS,FSH - the principal regulator of follicular growth and maturation [56] - is suppressed below the level needed in the early follicular phase to stimulate normal follicle maturation. As a result, the development of large antral follicles $(5-8 \mathrm{~mm})$ is arrested [57]. The arrested antral follicles will increase serum AMH in PCOS women due to greater production of $\mathrm{AMH}$ per follicle [58, 59].
The PCOS subgroups differed significantly on almost all anthropometric, endocrine, and metabolic characteristics [60]. Thus, we analyzed the association of each subgroup separately with the SNPs to determine the variations with different clinical variables. Accordingly, we detected significant correlation of THADA rs13429458 variant, TOX3 rs4784165variant with the OA+PCOM subgroup, and HMGA2 rs2272046variant with the HA+PCOM subgroup. TOX3 and HMGA2 genes are well-known contributors to PCOS through enhancement of the activity of transcription factors such as the estrogen receptor [36] and promoting the proliferation of granulosa cells [38], respectively. No significant association of PCOS or its phenotypes with FSHR rs2268361, YAP1rs1894116, or $R A B 5 B$ rs705702 in the Saudi population, which could be attributed to the small sample size.

\section{Conclusion:}

We report the link between the THADA rs13429458 gene variant and PCOS in western population. We also document the link of THADA rs13429458 and TOX3 rs4784165 variants with combined OA and PCOM phenotype of PCOS patients. It is further noted that the HMGA2 rs2272046 variant is linked with combined HA and PCOM phenotypes. These observations should be further verified using large GWAS to delineate the polygenic risk in PCOS among Saudi population.

\section{Competing Interests:}

The authors declare that they have no competing interests.

Funding:

This study was funded by the Center of Innovation in Personalized Medicine (CIPM), King Abdulaziz University, Jeddah, Saudi Arabia.

\section{Authors' contribution:}

S.B. conceptualized the study. S.B. and N.A. performed experiments, analyzed data, and wrote the manuscript. S.B. corrected the final version of the manuscript. All authors read and approved the final manuscript.

\section{Acknowledgments:}

The authors would like to show great appreciation to Mrs. Angham Nawar, Radiology and Imaging technician at CIPM, and Mrs. Jawaher Alsaedi nurse at CIPM for collecting the blood samples from the subjects. In addition, the authors thank Mr. Salah Barnawi, Statistics Department, King Fahad Medical Research Centre, King Abdulaziz University, Saudi Arabia, for his valuable advice in statistical methods. 


\section{BIOINFORMATION}

\section{Discovery at the interface of physical and biological sciences}

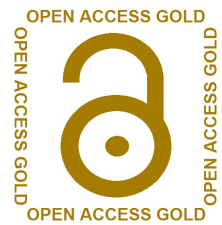

\section{References:}

[1] Trivax B \& Azziz R. Clin Obstet Gynecol. 2007 50:168. [PMID: 17304034]

[2] Rotterdam ESHRE/ASRM-Sponsored PCOS Consensus Workshop Group. Fertil Steril. 2004 81:19. [PMID: 14711538]

[3] Azziz R et al. J Clin Endocrinol Metab. 2006 91:4237. [PMID: 16940456]

[4] Legro RS et al. J Clin Endocrinol Metab. 2013 98:4565. [PMID: 24151290]

[5] Bozdag Get al. Hum Reprod. 2016 31:2841. [PMID: 27664216]

[6] March WA et al. Hum Reprod. 2010 25:544. [PMID: 19910321]

[7] Sirmans SM \& Pate KA. Clin Epidemiol. 2013 6:1. [PMID: 24379699]

[8] Alraddadi SM et al. World Journal of Pharmaceutical Research. 2018 7:231.

[9] Kakoly NS et al. Hum Reprod Update. 2018 24:455. [PMID: 29590375]

[10] Melo AS et al. Clinics (Sao Paulo). 2015 70:765. [PMID: 26602525]

[11] Moran LJ et al. Hum Reprod Update. 2010 16:347. [PMID: 20159883]

[12] Moran LJ et al. Fertil Steril. 2011 95:1742. [PMID: 21316662]

[13] Taponen S et al. J Clin Endocrinol Metab. 2004 89:2114. [PMID: 15126528]

[14] Wang ET et al. Obstet Gynecol. 2011 117:6. [PMID: 21173640]

[15] Zhao L et al. Oncotarget. 2016 7:33715. [PMID: 27220885]

[16] Azziz R et al. Fertil Steril. 2009 91:456. [PMID: 18950759]

[17] Azziz R et al. J Clin Endocrinol Metab. 2004 89:453. [PMID: 14764747]

[18] Carmina E et al. J Clin Endocrinol Metab. 2005 90:2545. [PMID: 15728203]

[19] Lizneva D et al. Fertil Steril. 2016 106:6. [PMID: 27233760]

[20] Moghetti P et al. J Clin Endocrinol Metab. 2013 98:E628. [PMID: 23476073]

[21] Welt CK et al. J Clin Endocrinol Metab. 2006 91:4842. [PMID: 17003085]

[22] Teede H et al. BMC Med. 2010 8:41. [PMID: 20591140]

[23] Chen ZJ et al. Nat Genet. 2011 43:55. [PMID: 21151128]

[24] Dumesic DA et al. Endocr Rev. 2015 36:487. [PMID: 26426951]

[25] Kahsar-Miller MD et al. Fertil Steril. 2001 75:53. [PMID: 11163816]

[26] Shi Y et al. Nat Genet. 2012 44:1020. [PMID: 22885925]

[27] Vink JM et al. J Clin Endocrinol Metab. 2006 91:2100. [PMID: 16219714]

[28] Day FR et al. Nat Commun. 2015 6:8464. [PMID: 26416764]

[29] Eriksen MB et al. PLoS One. 2013 8:e77186. [PMID: 24086769]
[30] Goodarzi MO et al. J Med Genet. 2012 49:90. [PMID: 22180642]

[31] Louwers YV et al. J Clin Endocrinol Metab. 2013 98:E2006. [PMID: 24106282]

[32] Welt CK et al. J Clin Endocrinol Metab. 2012 97:E1342. [PMID: 22547425]

[33] Drieschner N et al. Thyroid. 2006 16:1091. [PMID: 17123335]

[34] OFlaherty E \& Kaye J. BMC Genomics. 2003 4:13. [PMID: 12697058]

[35] Dittmer S et al. J Cell Sci. 2011 124:252. [PMID: 21172805]

[36] Yahata T et al. Genes Dev. 2001 15:2598. [PMID: 11581164]

[37] McAllister JM et al. Trends Endocrinol Metab. 2015 26:118. [PMID: 25600292]

[38] Yue CY et al. PLoS One. 2018 13:e0203129. [PMID: 30153296]

[39] Yang Y et al. Oncol Rep. 2018 39:3073. [PMID: 29693142]

[40] Edgar BA. Cell. 2006 124:267. [PMID: 16439203]

[41] Basu S et al. Mol Cell. 2003 11:11. [PMID: 12535517]

[42] Stenmark H. Nat Rev Mol Cell Biol. 2009 10:513. [PMID: 19603039]

[43] Stenmark H Olkkonen VM. Genome Biol. 2001 2:REVIEWS3007. [PMID: 11387043]

[44] Batarfi AA et al. BMC Med Genet. 2019 20:144. [PMID: 31429705]

[45] Ahmed N et al. Diagnostics (Basel). 2019 9. [PMID: 31581541]

[46] Bao S et al. Int J Clin Exp Pathol. 2016 11:11883.

[47] Zhao H et al. Hum Reprod. 2012 27:294. [PMID: 22081247]

[48] Eriksen MB et al. Eur J Obstet Gynecol Reprod Biol. 2012 163:39. [PMID: 22504079]

[49] Lerchbaum E et al. Horm Metab Res. 2011 43:743. [PMID: 22009367]

[50] Zeggini E et al. Nat Genet. 2008 40:638. [PMID: 18372903]

[51] Cui L et al. Hum Reprod. 2013 28:538. [PMID: 23208300]

[52] Cimino I et al. Nat Commun. 2016 7:10055. [PMID: 26753790]

[53] Chappel SC Howles C. Hum Reprod. 1991 6:1206. [PMID: 1752920]

[54] Durlinger AL et al. Reproduction. 2002 124:601. [PMID: 12416998]

[55] Grynnerup AG et al. Acta Obstet Gynecol Scand. 2012 91:1252. [PMID: 22646322]

[56] Howles CM, Mol Cell Endocrinol. 2000 161:25. [PMID: 10773387]

[57] Franks S et al. Hum Reprod Update. 2008 14:367. [PMID: 18499708]

[58] Bhide P et al. BJOG. 2015 122:1625. [PMID: 25286823]

[59] Nardo LG et al. Hum Reprod. 2009 24:2917. [PMID: 19617605]

[60] Huang CC et al. Hum Reprod. 2015 30:937. [PMID: 25662806] 


\section{BIOINFORMATION}

Discovery at the interface of physical and biological sciences

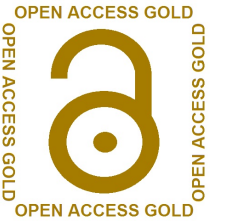

Edited by P Kangueane

Citation: Bakhashab \& Ahmed, Bioinformation 15(11): 812-819 (2019)

License statement: This is an Open Access article which permits unrestricted use, distribution, and reproduction in any medium, provided the original work is properly credited. This is distributed under the terms of the Creative Commons Attribution License 


\section{BIOINFORMATION}

Discovery at the interface of physical and biological sciences
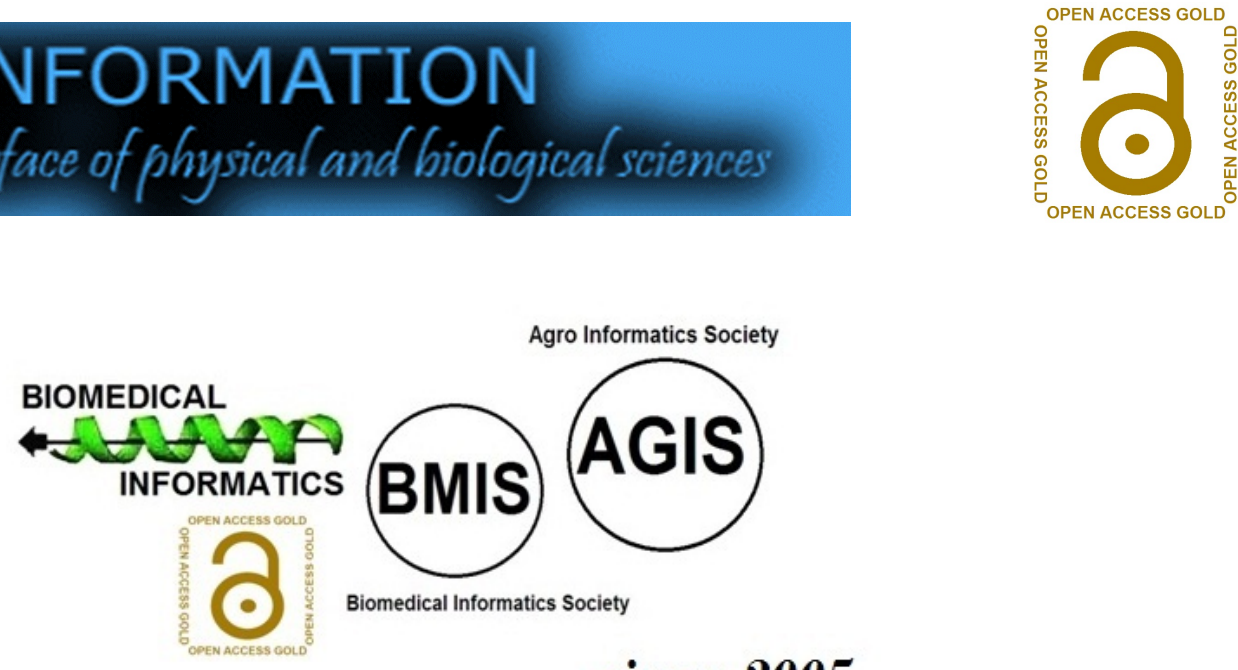

since 2005

\section{BIOINFORMATION}

Discovery at the interface of physical and biological sciences

\section{indexed in}

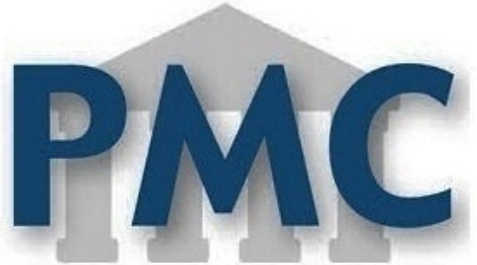

PublMed

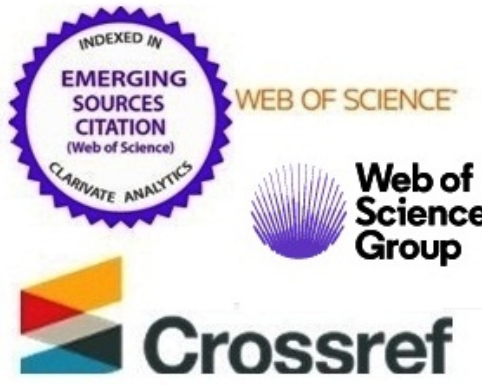

EBSCO

Web of

Science

roup

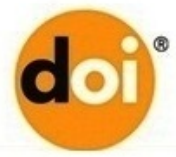

ResearchGate
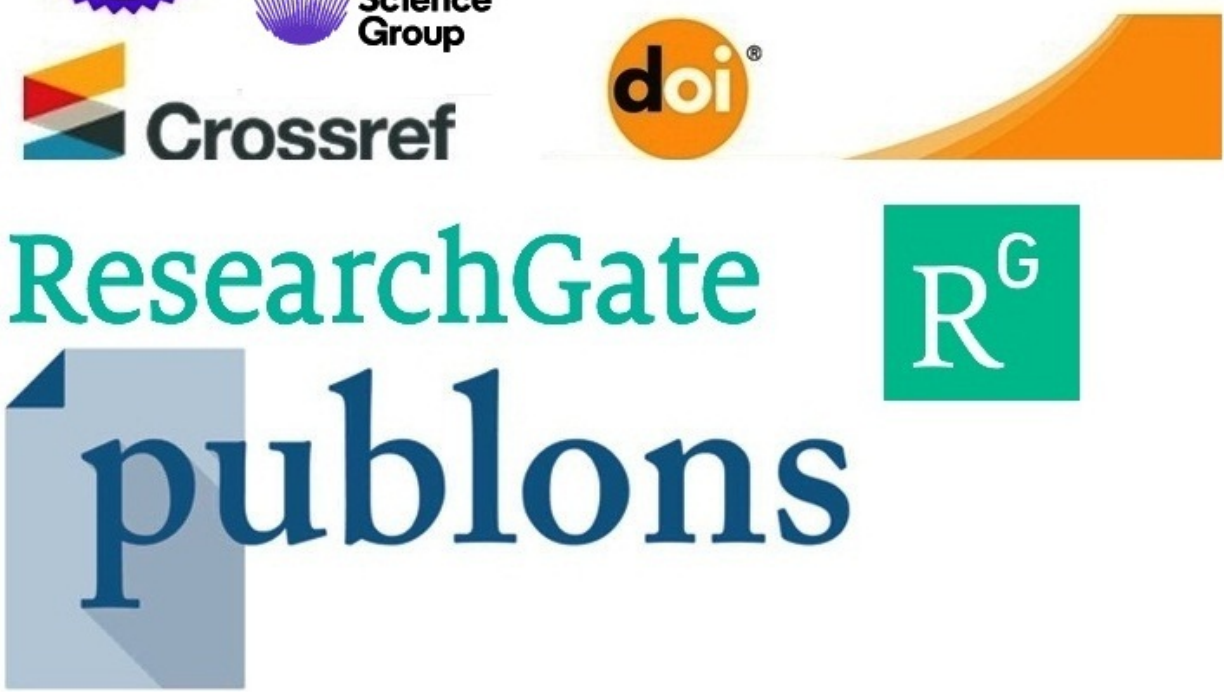